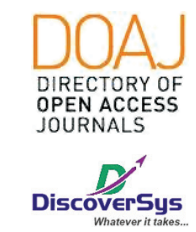

Published by DiscoverSys

\section{Gambaran kualitas hidup peserta Pos Binaan Terpadu Penyakit Tidak Menular (POSBINDU PTM) dengan kejadian hipertensi di wilayah kerja Unit Pelaksana Teknis (UPT) Puskesmas Abang I, Karangasem, Bali, Indonesia}

\author{
I Putu Sakamekya Wicaksana Sujaya, ${ }^{1 *}$ Ni Made Sri Nopiyani, ${ }^{2}$ Ni Wayan Meni
}

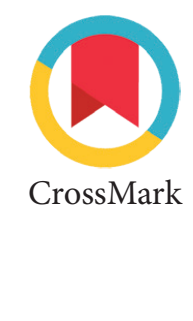

\section{ABSTRACT}

Background: Hypertension is a disease that is a significant problem in the world. The prevalence of hypertension worldwide based on JNC-7 covers more than two-thirds of individuals after the age of 65 years. Hypertension can have an impact on the quality of life of patients which is influenced by various complications. PTB with the occurrence of hypertension in UPT Puskesmas Abang I, Karangasem, Bali, Indonesia.

Methods: A cross-sectional study with a total sampling technique was conducted to the 5 villages in the Abang I Public Health Services during September-0ctober 2018. A total of 48 respondents who meet the inclusion and exclusion criteria were included in this study. The variables assessed included gender, age group, level of education, occupational status, degree of hypertension, and overall quality of life among respondents based on the SF-36 questionnaire. Data were analyzed using SPSS software version 17 for Windows.

Results: The gender proportion of females and males did not differ (50.00\%). Most respondents were $\geq 65$ years-old (54.17\%), followed by low education level (85.42\%), jobless (52.08\%), hypertension (HT) grade II (56.25\%), Rerata systolic blood pressure $159.5 \pm 18 \mathrm{mmHg}$, and diastolic blood pressure of $93 \pm 8 \mathrm{mmHg}$. Most respondents have a good quality of life in the domain of physical roles (100.00\%), health (58.33\%), vitality (60.41\%), emotions (64.58\%), and mental health (58.33\%).

Conclusion: The quality of life among respondents with hypertension at UPT Abang I Public Health Services, Karangasem, Bali, Indonesia showed good results in the domains of a physical role, health, vitality, emotions, and mental health.

Keywords: Quality of Life, POSBINDU TM, Hypertension, Abang I Public Health Services

Cite This Article: Sujaya, I.P.S.W., Nopiyani, N.M.S., Meni, N.W. 2020. Gambaran kualitas hidup peserta Pos Binaan Terpadu Penyakit Tidak Menular (POSBINDU PTM) dengan kejadian hipertensi di wilayah kerja Unit Pelaksana Teknis (UPT) Puskesmas Abang I, Karangasem, Bali, Indonesia. Intisari Sains Medis 11(1): 198-204. D0I: 10.15562/ism.v11i1.534

\title{
ABSTRAK
}

'Mahasiswa Program Studi Pendidikan Dokter, Fakultas Kedokteran, Universitas Udayana, Bali, Indonesia

${ }^{2}$ Departemen IImu Kedokteran Komunitas-IImu Kedokteran Pencegahan, Fakultas Kedokteran, Universitas Udayana, Bali, Indonesia

\section{*Korespondensi:}

I Putu Sakamekya Wicaksana Sujaya; Mahasiswa Program Studi Pendidikan Dokter, Fakultas Kedokteran, Universitas Udayana, Bali, Indonesia;

sakamekyaw@gmail.com

Diterima: 18-06-2019

Disetujui: 19-03-2020

Diterbitkan: 26-03-2020
Latar Belakang: Hipertensi adalah salah satu penyakit yang menjadi masalah utama di dunia. Prevalensi hipertensi di seluruh dunia berdasarkan JNC-7 mencakup lebih dari dua pertiga individu setelah usia 65 tahun. Hipertensi dapat berdampak pada kualitas hidup pasien dimana dipengaruhi oleh berbagai komplikasi penyertanya. Penelitian ini bertujuan untuk mengetahui gambaran kualitas hidup peserta POSBINDU PTM dengan kejadian hipertensi di UPT Puskesmas Abang I, Karangasem, Bali, Indonesia.

Metode: Penelitian ini menggunakan desain potong lintang dengan teknik Total Sampling pada 5 Desa di Kawasan UPT Kesmas Abang I selama September-Oktober 2018. Sebanyak 48 orang yang telah memasuki kriteria inklusi dan eksklusi dimasukkan dalam penelitian ini. Variabel yang dinilai meliputi jenis kelamin, kelompok usia, tingkat pendidikan, status pekerjaan, derajat hipertensi, dan kualitas hidup responden secara keseluruhan berdasarkan kuisioner SF-36. Data dianalisis menggunakan piranti lunak SPSS versi 17 untuk Windows. Hasil: Proporsi jenis kelamin perempuan dan laki-laki tidak berbeda (50\%). Sebagian besar pasien berusia $\geq 65$ tahun $(54,17 \%)$, diikuti dengan pendidikan rendah $(85,42 \%)$, tidak bekerja $(52,08 \%)$, hipertensi (HT) derajat II (56,25\%), rata-rata tekanan darah sistolik $159.5 \pm 18 \mathrm{mmHg}$, dan tekanan darah diastolik $93 \pm 8 \mathrm{mmHg}$. Sebagian besar responden memiliki kualitas hidup yang baik pada domain peran fisik (100,00\%), kesehatan (58,33\%), vitalitas $(60,41 \%)$, emosi (64,58\%), dan kesehatan mental (58,33\%).

Kesimpulan: Kualitas hidup responden dengan hipertensi di UPT Puskesmas Abang I, Karangasem, Bali, Indonesia menunjukkan hasil yang baik pada domain peran fisik, kesehatan, vitalitas, emosi, dan kesehatan mental. 


\section{PENDAHULUAN}

Hipertensi adalah salah satu penyakit yang menjadi masalah utama di dunia. Menurut Joint National Committee on Prevention, Detection, Evaluation and Treatment of High Blood Pressure (JNC-7), hipertensi terjadi pada lebih dari dua pertiga individu setelah usia 65 tahun. ${ }^{1}$ Data dari Framingham Heart Study, pada pria dan wanita yang bebas hipertensi pada usia 55 tahun menunjukkan akan terjadi pengembangan hipertensi sampai usia 80 tahun dengan persentase $91 \%-93 \% .^{2}$ Pada tahun 2005, kematian yang diakibatkan oleh penyakit jantung dan pembuluh darah di Indonesia adalah sebesar $26,3 \%$, dengan faktor utama yang mempengaruhi adalah hipertensi. ${ }^{3}$ Hipertensi meningkatkan risiko penyakit kardiovaskular sebesar 2 kali lipat, meliputi penyakit jantung koroner, gagal jantung kongestif, stroke iskemik dan hemoragik, gagal ginjal, dan penyakit arteri perifer. ${ }^{4}$ Berkaitan dengan hal tersebut maka hipertensi telah dianggap sebagai salah satu faktor risiko utama terjadinya kematian. ${ }^{4}$

Masalah kualitas hidup pasien dewasa ini mendapat perhatian yang sungguh- sungguh karena penatalaksanaan penyakit diharapkan tidak hanya menghilangkan gejala tapi juga dapat meningkatkan kualitas hidup. Peningkatan jumlah penderita hipertensi terutama pada lansia dengan segala masalah biopsikososial yang ditimbulkan telah berakibat pada penurunan kualitas hidup penderitanya. ${ }^{5}$ Pada penelitian yang dilakukan oleh Trevisol DJ dkk ditemukan bahwa pada individu yang menderita hipertensi, memiliki kualitas hidup yang lebih rendah dibandingkan pada individu dengan tekanan darah yang normal (normotensi). ${ }^{6}$ Kualitas hidup telah menjadi perhatian oleh banyak ahli sejak akhir tahun 1980-an. Kualitas hidup tidak hanya menyangkut penilaian individu terhadap posisi mereka dalam hidup, melainkan juga adanya konteks sosial dan juga konteks lingkungan sekitar yang juga mempengaruhi kualitas hidup. Penelitian Hayes DK dkk diketahui bahwa 30\% responden yang menderita hipertensi cenderung menyebutkan bahwa dirinya memiliki status kesehatan yang buruk dibandingkan dengan yang tidak hipertensi. ${ }^{7}$ Kualitas hidup mendeskripsikan istilah yang merujuk pada emosional, sosial dan kesejahteraan fisik seseorang, juga kemampuan mereka untuk berfungsi dalam kehidupan sehari-hari. ${ }^{8}$ Pada responden lansia dengan hipertensi memiliki kualitas hidup yang buruk lebih banyak dibandingakan dengan kualitas hidup normotensif.

Menurut data Dinas Kesehatan Provinsi Bali, hipertensi esensial berada pada urutan kedua dari 10 Besar Penyakit pada Pasien Rawat Jalan di RSUD di Provinsi Bali tahun 2014 dengan jumlah 6801 penderita. ${ }^{9}$ Pada wilayah kerja Puskesmas Abang I, hipertensi merupakan penyakit tidak menular terbanyak kedua setelah artritis. Pada tahun 2016, jumlah insidens hipertensi terdaftar di Puskesmas Abang 1 adalah 488 orang. Namun, tahun ini, besar insidens meningkat yaitu sejumlah 490 orang tehitung dari bulan Januari sampai bulan Agustus $2018 .{ }^{10}$ Hal ini menunjukkan adanya peningkatan pasien hipertensi di wilayah kerja Puskesmas Abang I.

POSBINDU adalah pusat bimbingan pelayanan kesehatan yang dikelolah dan diselenggarakan untuk dan oleh masyarakat dengan dukungan teknis dari petugas kesehatan dalam rangka pencapai masyarakat yang sehat dan sejahtera. Secara umum, upaya kesehatan yang terdiri dari dua unsur utama yaitu upaya kesehatan masyarakat dan perorangan yang diselenggarakan oleh Puskesmas Abang I untuk pengendalian penyakit tidak menular termasuk hipertensi, obesitas dan kanker serviks adalah Pos Pembinaan Terpadu Penyakit Tidak Menular (POSBINDU PTM) melalui sosialisasi gaya hidup sehat dan melalui skrining terhadap masyarakat yang berumur 18 tahun ke atas. Hasil wawancara awal menunjukkan bahwa POSBINDU wilaya kerja Puskesmas Abang I memiliki kegiatan yang cukup komprehensif, pemeriksaan kesehatan, pemberian makanan tambahan (PMT), senaman lansia, pembinaan spiritual, serta program rekreasi namun belum pernah ada penelitian yang mengukur manfaat POSBINDU terhadap kualitas hidup peserta. Oleh karena itu penelitian ini bertujuan untuk mengetahui ada gambaran kualitas hidup peserta POSBINDU PTM di Puskesmas Abang 1, Karangasem menggunakan instrumen kualitas hidup 36-item Short-Form and Health Survey (SF-36).

\section{METODE}

Rancangan penelitian ini adalah potong lintang deskriptif dengan menggunakan teknik Total Sampling pada 5 desa Kawasan UPT Kesmas Abang I selama periode September-Oktober 2018. Proses pengumpulan data dilakukan di POSBINDU yang berada di wilayah kerja Puskesmas Abang I terhadap 48 responden yang telah memenuhi kriteria inklusi dan eksklusi. Kriteria inklusi penelitian ini adalah terdiagnosis hipertensi sesuai data penanggung jawab Program Penanggulangan Penyakit Tidak Menular (P2PTM), tinggal di wilayah kerja Puskesmas Abang I, terdaftar sebagai peserta POSBINDU sesuai data dari Bidan yang bertanggung jawab di tiap desa tempat diselenggarakannya POSBINDU dan bersedia menjadi responden penelitian. Sedangkan kriteria eksklusi adalah responden menolak berpartisipasi, pasien dengan 
kondisi kesehatan yang tidak memungkinkan untuk berpartisipasi, maupun pasien tidak kooperatif

Data penelitian ini merupakan data primer, dimana semua data yang diperlukan diperoleh dari hasil penyebaran kuesioner. Kuesioner yang digunakan adalah kuesioner mengenai karakteristik sosiodemografis responden, tekanan darah dan derajat hipertensi, kuesioner Short Form -36 (SF-36) (instrument baku untuk menilai kualitas hidup terutama untuk pasien yang menderita penyakit kronis).

Data yang merupakan hasil tahap pengumpulan data akan diolah melalui beberapa tahapan sebagai berikut yakni editing, recoding, scoring, entering, dan tabulating. Data selanjutnya dianalisis menggunakan bantuan perangkat lunak Statistical Package for the Social Science (SPSS) versi 17 untuk Windows. Karakteristik subjek serta kualitas hidup responden akan disajikan secara deskriptif dalam bentuk tabel distribusi frekuensi. Selain itu data yang tersedia dilakukan tabulasi silang antara kualitas hidup dalam 8 domain dengan karakteristik sosiodemografis, dalam kasus ini kelompok usia, dan status pekerjaan dan derajat hipertensi.

\section{HASIL PENELITIAN}

Hasil pada Tabel 1 menunjukkan bahwa perbandingan jumlah responden laki-laki dan perempuan adalah sama besar yaitu masing-masing sebanyak 24 orang $(50,00 \%)$. Rentang usia $\geq 65$ tahun, atau kategori lansia sebanyak 26 orang (54,17\%) lebih banyak dibandingkan dengan responden dengan usia $<65$ tahun (Tabel 1). Dilihat dari faktor tingkat pendidikan, proporsi terbanyak yakni responden dengan tingkat pendidikan rendah sebanyak 41 orang $(85,42 \%)$. Status pekerjaan responden penelitian lebih banyak responden yang tidak bekerja yaitu 25 orang $(52,08 \%)$ dibandingkan dengan status perkerjaan responden yang bekerja yaitu 23 orang $(47,91 \%)$. Sedangkan berdasarkan hasil pengukuran tekanan darah pada 48 responden pada saat pelaksanaan POSBINDU didapatkan 27 orang $(56,25 \%)$ menderita Hipertensi derajat II dan 21 responden (43,75\%) menderita Hipertensi derajat I (Tabel 1). Hasil pengukuran rata-rata tekanan darah sistolik responden adalah $159,5 \pm 18 \mathrm{mmHg}$ dan tekanan darah diastolik $93 \pm 8$ mmHg (Tabel 1).

Berdasarkan Tabel 2, nilai rerata dari seluruh domain tidak ada yang mencapai nilai 60 , dan skor cut off berkisar antara 25 (nilai median dari peran fisik) sampai 66 (median dari peran emosional). Pada domain fungsi fisik, sebanyak $52 \%$ responden (25 orang) memiliki kualitas hidup di bawah nilai Rerata (53.5) yang berarti buruk. Sebanyak 56\% responden (27 orang) mendapatkan nilai buruk pada domain nyeri tubuh dengan cut off score berupa nilai Rerata 54.4 (Tabel 2). Pada domain peran fisik, 100\% (48 orang) mendapatkan nilai di atas cut off score, namun ini bisa jadi disebabkan karena nilai median yang digunakan sebagai cut

Tabel 1 Karakteristik responden berdasarkan sosiodemografi

\begin{tabular}{|c|c|c|c|}
\hline Karakteristik & Frekuensi $(\mathrm{N}=48)$ & Proporsi (\%) & Rerata \pm SB \\
\hline \multicolumn{4}{|l|}{ Jenis Kelamin } \\
\hline Laki-laki & 24 & $50,00 \%$ & \\
\hline Perempuan & 24 & $50,00 \%$ & \\
\hline \multicolumn{4}{|l|}{ Kelompok Usia } \\
\hline$<65$ tahun & 22 & $45.83 \%$ & \\
\hline$\geq 65$ tahun & 26 & $54.17 \%$ & \\
\hline \multicolumn{4}{|l|}{ Tingkat Pendidikan } \\
\hline Pendidikan Rendah & 41 & $85,42 \%$ & \\
\hline Pendidikan Tinggi & 7 & $14,58 \%$ & \\
\hline \multicolumn{4}{|l|}{ Status Pekerjaan } \\
\hline Bekerja & 23 & $47,91 \%$ & \\
\hline Tidak Bekerja & 25 & $52,08 \%$ & \\
\hline \multicolumn{4}{|c|}{ Derajat Hipertensi (HT) } \\
\hline Derajat I & 21 & $43,75 \%$ & \\
\hline Derajat II & 27 & $56,25 \%$ & \\
\hline \multicolumn{4}{|c|}{ Tekanan Darah (mmHg) } \\
\hline Sistolik & & & $159.5 \pm 18$ \\
\hline Diastolik & & & $93 \pm 8$ \\
\hline
\end{tabular}


Tabel 2 Distribusi kualitas hidup responden secara keseluruhan

\begin{tabular}{|c|c|c|c|}
\hline Domain Kualitas Hidup & Frekuensi $(\mathrm{N}=48)$ & Proporsi (\%) & Rerata (Median) \pm SB \\
\hline \multicolumn{4}{|l|}{ Fungsi Fisik } \\
\hline Baik & 23 & 47,91 & $53,5(50) \pm 29,1$ \\
\hline Buruk & 25 & 52,08 & \\
\hline \multicolumn{4}{|l|}{ Peran Fisik } \\
\hline Baik & 48 & 100,00 & $47.92(25) \pm 27,7$ \\
\hline Buruk & 0 & 0,00 & \\
\hline \multicolumn{4}{|l|}{ Nyeri Tubuh } \\
\hline Baik & 21 & 43,75 & $54,4(50) \pm 25,3$ \\
\hline Buruk & 27 & 56,25 & \\
\hline \multicolumn{4}{|l|}{ Kesehatan Umum } \\
\hline Baik & 28 & 58,33 & $58,5(60) \pm 20,3$ \\
\hline Buruk & 20 & 41,67 & \\
\hline \multicolumn{4}{|l|}{ Vitalitas } \\
\hline Baik & 29 & 60,41 & $50,0(51) \pm 26,2$ \\
\hline Buruk & 19 & 39,59 & \\
\hline \multicolumn{4}{|l|}{ Fungsi Sosial } \\
\hline Baik & 24 & 50,00 & $57,5(56.5) \pm 17,0$ \\
\hline Buruk & 24 & 50,00 & \\
\hline \multicolumn{4}{|l|}{ Peran Emosi } \\
\hline Baik & 31 & 64,58 & $59,0(66) \pm 19,5$ \\
\hline Buruk & 17 & 35,42 & \\
\hline \multicolumn{4}{|l|}{ Kesehatan Mental } \\
\hline Baik & 28 & 58,33 & $51,2(52) \pm 20,0$ \\
\hline Buruk & 20 & 41,67 & \\
\hline
\end{tabular}

Tabel 3 Perbedaan nilai kualitas hidup SF-36 berdasarkan usia

\begin{tabular}{lcccc}
\hline & \multicolumn{2}{c}{ Usia (Rerata \pm SB) } & & \\
\cline { 2 - 3 } Domain & $<\mathbf{6 5}$ tahun & $\mathbf{2 6 5}$ tahun & Perbedaan Rerata & P \\
\hline Fungsi Fisik & $72,50 \pm 22,77$ & $37,50 \pm 24,05$ & 35,00 & 0,000 \\
Peran Fisik & $67,05 \pm 28,23$ & $31,73 \pm 13,37$ & 35,31 & 0,000 \\
Nyeri Tubuh & $65,41 \pm 19,75$ & $45,04 \pm 26,12$ & 20,37 & 0,004 \\
Kesehatan Umum & $66,14 \pm 15,27$ & $52,12 \pm 22,00$ & 14,02 & 0,015 \\
Vitalitas & $61,50 \pm 19,59$ & $39,60 \pm 27,20$ & 21,92 & 0,003 \\
Fungsi Sosial & $65,14 \pm 14,15$ & $51,12 \pm 16,90$ & 14,02 & 0,003 \\
Peran Emosi & $64,62 \pm 20,01$ & $56,69 \pm 19,16$ & 7,50 & 0,186 \\
Kesehatan Mental & $62,70 \pm 12,74$ & $41,54 \pm 20,28$ & 21,14 & 0,000 \\
\hline
\end{tabular}

off score domain peran fisik terlampau kecil, yaitu hanya sebesar 25. Pada domain kesehatan secara umum, 58\% responden (28 orang) memiliki nilai di atas cut off score yang berarti jumlah responden dengan kesehatan umum baik lebih banyak daripada responden dengan kualitas hidup buruk secara umum, dimana cut off score yang dipakai adalah nilai Rerata (58.5) (Tabel 2).
Pada domain vitalitas didapatkan 60\% responden (29 orang) mendapat skor baik di atas nilai cut off menggunakan nilai Rerata sebesar 50. Pada domain peran emosi, 65\% responden memperoleh nilai di atas nilai cut off menggunakan nilai median yaitu 66, dan masuk dalam kualitas baik. Selanjutnya 58,3\% responden (28 orang) mendapatkan nilai baik pada domain kualitas mental, 
Tabel 4 Perbedaan derajat hipertensi terhadap nilai kualitas hidup SF-36

\begin{tabular}{lcccc}
\hline & \multicolumn{2}{c}{ Derajat Hipertensi (Rerata \pm SB) } & & \\
\cline { 2 - 3 } Domain & Derajat I & Derajat II & Perbedaan Rerata & P \\
\hline Fungsi Fisik & $76,19 \pm 18,29$ & $35,93 \pm 23,33$ & 40,26 & 0,000 \\
Peran Fisik & $61,90 \pm 31,24$ & $37,04 \pm 18,82$ & 24,87 & 0,001 \\
Nyeri Tubuh & $67,24 \pm 21,54$ & $44,37 \pm 23,81$ & 22,87 & 0,001 \\
Kesehatan Umum & $67,38 \pm 17,36$ & $51,67 \pm 20,00$ & 15,71 & 0,006 \\
Vitalitas & $62,10 \pm 20,98$ & $39,93 \pm 26,05$ & 22,62 & 0,003 \\
Fungsi Sosial & $66,38 \pm 14,75$ & $50,67 \pm 15,70$ & 15,71 & 0,001 \\
Peran Emosi & $64,00 \pm 20,14$ & $54,81 \pm 18,38$ & 9,18 & 0,106 \\
Kesehatan Mental & $64,52 \pm 12,73$ & $40,89 \pm 18,79$ & 23,63 & 0,000 \\
\hline
\end{tabular}

karena mendapatkan skor di atas cut off point yang digunakan yaitu nilai Rerata 51,2 (Tabel 2). Kualitas hidup pada domain fungsi sosial memiliki frekuensi responden dengan kualitas hidup baik yang sama banyaknya dengan frekuensi responden dengan kualitas hidup buruk yaitu masing-masing sebesar 50\% (24 orang) (Tabel 2).

Pada Tabel 3, hasil penelitian menunjukkan terdapat perbedaan kualitas hidup yang bermakna antara responden kelompok usia $<65$ tahun dibandingkan dengan responden pada kelompok usia $\geq 65$ tahun pada beberapa domain yaitu: Fungsi fisik, peran fisik, nyeri tubuh, kesehatan umum, vitalitas, fungsi sosial, dan kesehatan mental $(\mathrm{p}<0,05)$. Sedangkan perbedaan yang tidak bermakna $(\mathrm{p}>0,05)$ hanya ditemukan pada domain peran emosi (Tabel 3).

Perbedaan rerata skor dari tiap domain antara kelompok usia $<65$ tahun dan $\geq 65$ tahun adalah 35,00 pada domain fungsi fisik, 35,31 pada domain peran fisik, 20,37 pada domain nyeri tubuh, 14,02 pada domain kesehatan umum, 21,92 pada domain vitalitas, 14,02 pada domain fungsi sosial, 7,5 pada domain peran emosi, 21,14 pada domain kesehatan mental (Tabel 3).

Pada Tabel 4, hasil penelitian menunjukkan bahwa sebagian besar domain kualitas hidup kelompok responden dengan Hipertensi derajat I memiliki kualitas hidup yang lebih baik dibandingkan dengan kelompok responden dengan hipertensi derajat II secara bermakna $(p<0,05)$. Dari delapan domain penilaian kualitas hidup, 6 domain memiliki perbedaan yang bermakna $(\mathrm{p}<0,05)$ yaitu pada domain fungsi fisik, peran fisik, nyeri tubuh, vitalitas, fungsi sosial, dan kesehatan mental. Sedangkan 2 domain lainnya memiliki nilai perbedaan yang tidak bermakna $(p>0,05)$ yaitu pada domain kesehatan secara umum dan peran emosi (Tabel 4).

Perbedaan rerata skor dari tiap domain antara responden dengan Hipertensi derajat I dan derajat II adalah sebagai berikut: 40,26 pada domain fungsi fisik, 24,87 pada domain peran fisik, 22,87 pada domain nyeri tubuh, 15,71 pada domain kesehatan umum, 22,62 pada domain vitalitas, 15,71 pada domain fungsi sosial, 9,18 pada domain peran emosi, 23,63 pada domain kesehatan mental (Tabel 4).

\section{PEMBAHASAN}

Hasil penelitian menunjukan kualitas hidup peserta POSBINDU dengan hipertensi memiliki kualitas hidup yang buruk pada domain fungsi fisik. Penelitian ini serupa dengan penelitian yang telah di lakukan oleh Agusti MRP yang mengatakan bahwa terjadinya komplikasi pada hipertensi berimplikasi dengan terjadinya penurunan fungsi fisik pada penderita hipertensi. ${ }^{11}$ Berdasarakan penelitian serupa sebelumnya, $62.1 \%$ pasien dengan hipertensi mengalami komplikasi ke jantung, sedangkan yang mengalami komplikasi pada pembuluh darah perifer dan mata sebesar $10.3 \%$, komplikasi pada otak $21 \%$ dan komplikasi pada ginjal 25.2\%. ${ }^{11}$ Pada domain nyeri tubuh kualitas hidup yang buruk pada peserta POSBINDU lebih tinggi, hal ini bisa disebabkan karena gejala hipertensi memberikan nyeri pada penderitanya khususnya nyeri pada kepala dan mata dan komplikasi pada hipertensi seperti stroke, gagal ginjal dan penyakit jantung juga ikut berperan dalam nyeri yang dialami oleh penderita hipertensi. ${ }^{12}$ Namun perbandingan proporsi responden dengan kualitas hidup yang baik dan buruk pada tiap domain tidak berbeda jauh, sehingga dibutuhkan antisipasi pada tiap domain agar tidak terjadi peningkatan angka kualitas hidup yang buruk pada peserta POSBINDU.

Berdasarkan penelitian mengenai hubungan kempok usia dengan kualitas hidup, total rata-rata skor komponen kesehatan fisik responden usia $<65$ tahun lebih tinggi dibandingkan responden usia $\geq 65$ tahun. Berdasarkan hasil penelitian sebelumnya diketahui bahwa responden hipertensi usia $<65$ tahun memiliki rata-rata skor komponen kesehatan fisik lebih tinggi dibandingkan responden 
hipertensi usia $>65$ tahun, disebabkan karena pada saat terjadinya proses penuaan terjadi penurunan fungsi tubuh sebagai akibat dari perubahan fisiologis dan fungsional, individu lebih rentan terhadap penyakit kronis yang dapat mempengaruhi kualitas hidup dan perubahan pada aspek fisik dan peran fisik. ${ }^{13,14}$ Penelitian ini juga memaparkan adanya perbedaan antara skor total komponen kesehatan fisik yang disebabkan karena perbedaan antara rata-rata domain fungsi fisik dan rata-rata domain peran fisik terhadap responden usia $<65$ tahun dan responden usia $\geq 65$ tahun. Rata-rata domain fungsi fisik berusia $<65$ tahun lebih baik dibandingkan responden berusia $\geq 65$ tahun, hal ini dapat disebabkan ketika terjadinya peningkatan usia dan diikuti dengan terjadinya proses penuaan,responden mengalami keterbatasan dalam fungsi fisik dan juga peran fisik

Penelitian lainnya yang serupa juga mengungkapkan bahwa kualitas hidup kelompok lansia dengan hipertensi cenderung buruk terutama pada domain kesehatan fisik. ${ }^{15}$ Hal ini disebabkan karena setelah memasuki masa lansia, maka responden akan mengalami penurunan kesehatan fisik sehingga responden menjadi malas melakukan aktivitas fisik seperti olahraga dan bahkan dengan semakin lamanya durasi penyakit, maka responden cenderung tidak beraktifitas. ${ }^{15}$

Pada domain nyeri, terdapat perbedaan antara rerata nilai responden usia $<65$ tahun dan responden $>65$ tahun. Nyeri pada hipertensi dapat disebabkan oleh beberapa hal yaitu nyeri kepala yang dirasakan oleh penderita hipertensi yang menjadi salah satu tanda dan gejala hipertensi serta komplikasi yang disebabkan oleh hipertensi akan meningkatkan angka nyeri terutama pada pasien lansia yang memiliki hipertensi dengan berbagai macam komplikasi. ${ }^{16}$ Pada domain kesehatan umum terdapat perbedaan antara rerata skor domain kesehatan umum terhadap responden usia $<65$ tahun dan responden $\geq 65$ tahun. Hal ini dikarenakan responden yang berusia $<65$ cenderung lebih rutin memeriksakan kesehatannya secara rutin pada pusat pelayanan kesehatan, sedangkan responden dengan usia $>65$ tahun kurang rutin memeriksakan kesehatan umumnya dikarenakan pada usia > 65 tahun kemampuan untuk melakukan aktifitas akan semakin menurun dan responden tidak dapat pergi sendiri untuk memeriksakan kesehatannya sehingga dibutuhkanpendamping yang bersedia unttuk menemani apabila ingin memeriksakan kesehatannya sendiri seperti pada penelitian sebelumnya. ${ }^{14}$

Pada penelitian ini menunjukkan total ratarata skor komponen kesehatan mental responden menunjukkan terdapat perbedaan antara rata-rata total skor komponen kesehatan mental terhadap responden usia $<65$ tahun dan responden usia $\geq 65$ tahun. Penelitian Agusti MRP menunjukkan adanya perbedaan antara usia $<65$ tahun dan $>65$ tahun terhadap kualitas hidup pada komponen kesehatan mental, yaitu responden usia $<65$ tahun memiliki komponen kesehatan mental lebih buruk dibandingkan dengan responden usia $<65$ tahun. ${ }^{11} \mathrm{Hal}$ itu disebabkan karena ketika memasuki lansia orang akan lebih mudah mengalami penyakit-penyakit kronis salah satunya adalah hipertensi, orang yang mendekati usia lansia cenderung akan mengalami penurunan fungsi tubuh seperti penuruna fungsi fisik, fungsi kognitifdan psikomotorik yang menyebabkan terganggunya kemampuan lansia untuk melakukan aktifitas seperti bersosialisasi dengan lingkungan sekitarnya sehingga menyebabkan kondisinya akan semakin menurun dan diikuti mental mulai menurun. ${ }^{11}$ Hal ini menyebabkan penurunan kualitas hidup psikososial lansia menurun ditandai dengan terdapat penurunan kualitas hidup domain fungsi sosial, vitalitas dan kesehatan mental.

Pada penelitian ini didapatkan bahwa komponen peran emosi terhadap hipertensi derajat 2 skor totalnya tertinggi sebanyak dibandingkan dengan komponen lain pada derajat 2 tersebut. Demikian, domain kesehatan mental dapat bertanggung jawab untuk mengubah rasa sakit dan vitalitas domain karena somatisasi disebabkan oleh kesadaran memiliki penyakit. Fenomena ini telah ditunjukkan dalam sebuah penelitian yang dilakukan di Jepang, yang mengamati bahwa perubahan dalam domain kesehatan mental bertanggung jawab untuk memperburuk domain HRQL lainnya yang dinilai oleh SF-36. ${ }^{17}$

Di samping itu, hasil rata-rata skor domain fungsi fisik responden di kecamatan Karangasem memiliki rata-rata skor terendah dibandingkan dengan skor domain peran fisik, nyeri tubuh, kesehatan umum, vitalitas, fungsi social, peran emosi, dan kesehatan mental. Penelitian Dewhurst MJ pada lansia di Tanzania, dimana didapatkan prevalensi hipertensi pada lansia cukup tinggi yaitu $69.9 \%$ dari 2223 lansia. ${ }^{18} \mathrm{Hal}$ ini juga sejalan dengan hasil penelitian ini dimana kejadian hipertensi menempati sebagian besar kasus pada orang yang berusia diatas 60 tahun.

\section{SIMPULAN}

Secara keseluruhan kualitas hidup peserta POSBINDU PTM dengan hipertensi di wilayah UPT kesmas Abang 1 memiliki skor yang buruk pada domain fungsi fisik dan nyeri tubuh. Sebagian besar peserta POSBINDU PTM memiliki kualitas hidup yang baik pada domain peran fisik, kesehatan secara umum, vitalitas, fungsi social, domain 
peran emosi, dan kesehatan mental. Terdapat perbedaan kualitas hidup yang signifikan antara peserta POSBINDU dengan hipertensi yang berusia $<65$ tahun dan $>=65$ tahun dan antara peserta dengan hipertensi derajat 1 dan 2 .

\section{KONFLIK KEPENTINGAN}

Tidak terdapat konflik kepentingan dalam penulisan laporan penelitian ini.

\section{ETIKA PENELITIAN}

Persetujuan etik telah diterima oleh Komisi Etik, Fakultas Kedokteran, Universitas Udayana, Bali, Indonesia sebelum penelitian berjalan.

\section{PENDANAAN}

Tidak ada

\section{KONTRIBUSI PENULIS}

Seluruh penulis berkontribusi terhadap penulisan laporan penelitian ini baik dari tahap penyusunan proposal penelitian, mengumpulkan data, hingga interpretasi hasil penelitian yang ditulis dalam bentuk publikasi ilmiah.

\section{DAFTAR PUSTAKA}

1. Chobanian AV, Bakris GL, Black HR, Cushman WC, Green LA, Izzo JL et al. The Seventh Report of the Joint National Committee on Prevention, Detection, Evaluation, and Treatment of High Blood Pressure: the JNC 7 report. JAMA. 2003;289(19):2560-2572.

2. Mahmood SS, Levy D, Vasan RS, Wang TJ. The Framingham Heart Study and the epidemiology of cardiovascular disease: a historical perspective. Lancet. 2014;383(9921):999-1008.

3. Fithria, Isnaini M. Faktor-Faktor yang Berhubungan dengan Kepatuhan Berobat pada Penderita Hipertensi di Klinik Sumber Sehat Indrapuri Aceh Besar. Idea Nursing Jurnal. 2014;5(2):56-66.

4. Then KL, Rankin JA. Hypertension: a review for clinicians. Nurs Clin North Am. 2004;39(4):793-814.

5. Uchmanowicz B, Chudiak A, Mazur G. The influence of quality of life on the level of adherence to therapeutic recommendations among elderly hypertensive patients. Patient Prefer Adherence. 2018;12:2593-2603.
6. Trevisol DJ, Moreira LB, Kerkhoff A, Fuchs SC, Fuchs FD. Health-related quality of life and hypertension: a systematic review and meta-analysis of observational studies. J Hypertens. 2011;29(2):179-188.

7. Hayes DK, Denny CH, Keenan NL, Croft JB, Greenlund KJ. Health-related quality of life and hypertension status, awareness, treatment, and control: National Health and Nutrition Examination Survey, 2001--2004. J Hypertens. 2008;26(4):641-647.

8. Post MW. Definitions of quality of life: what has happened and how to move on. Top Spinal Cord Inj Rehabil. 2014;20(3):167-180.

9. Dinas Kesehatan Provinsi Bali. Prevalensi 10 Besar Penyakit di Bali. Pemerintah Provinsi Bali. 2015

10. Puskesmas Abang I. Gambaran Kasus Hipertensi di Wilayah UPT Puskesmas Abang I, Karangasem, Bali, Indonesia. Pemerintah Daerah Karangasem. 2018

11. Agusti MRP, Lestariningsih. Hubungan Hipertensi Derajat 1 Dan 2 Pada Obesitas Terhadap Komplikasi Organ Target Di Rsup Dr Kariadi Semarang. Jurnal Kedokteran Diponegoro. 2014;3(1):1-15

12. Kotchen TA, Kotchen JM, O'Shaughnessy IM. Insulin and hypertensive cardiovascular disease. Curr Opin Cardiol. 1996;11(5):483-489.

13. Low G, Molzahn AE. Predictors of quality of life in old age: a cross-validation study. Res Nurs Health. 2007;30(2):141150. doi: 10.1002/nur.20178

14. Pertiwi GAR, Aryawangsa AAN, Prabawa IPY, Manuaba IBAP, Bhargah A, Ratni NWS, et al. Factors associated with visit-to-visit variability of blood pressure in hypertensive patients at a Primary Health Care Service, Tabanan, Bali, Indonesia. Family Medicine and Community Health. 2018;6(4):191-199.

15. Rondón García LM, Ramírez Navarrro JM. The Impact of Quality of Life on the Health of Older People from a Multidimensional Perspective. J Aging Res. 2018;2018:4086294.

16. Saccò M, Meschi M, Regolisti G, Detrenis S, Bianchi L, Bertorelli $\mathrm{M}$, et al. The relationship between blood pressure and pain. J Clin Hypertens (Greenwich). 2013;15(8):600-605.

17. Fukuhara S, Bito S, Green J, Hsiao A, Kurokawa K. Translation, adaptation, and validation of the SF-36 Health Survey for use in Japan. J Clin Epidemiol. 1998;51(11):1037-1044.

18. Dewhurst MJ, Dewhurst F, Gray WK, Chaote P, Orega GP, Walker RW. The high prevalence of hypertension in rural-dwelling Tanzanian older adults and the disparity between detection, treatment and control: a rule of sixths? J Hum Hypertens. 2013;27(6):374-380.

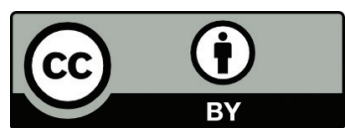

This work is licensed under a Creative Commons Attribution 